\title{
MODELS AND INNOVATING APPROACH TO INSTITUTIONAL REGULATION OF VOLUNTEERISM AS A SOCIAL COMMUNITY
}

\author{
Denislava Angelova \\ Ph.D. Chernorizetc Hrabar Varna Free University, Varna, Bulgaria,denislava.angelova@gmail.com
}

\begin{abstract}
The article examined models of institutional regulation of volunteering. The following are analyzed: institutional conditions for the functioning of the social community of volunteers; the nature of support and stimulating the development of volunteerism; the possibility of using the experience of other countries in the field of regulation of volunteerism.
\end{abstract}

Keywords: volunteerism, innovation, institutional regulation, social activity, socially useful behavior model.

\section{INTRODUCTION}

One of the dominant ideas useful in the process of educational and pedagogical activity is the socialization of the individual in a form corresponding to the necessary profile of an individual to serve society. At the same time, the desire of adolescents to participate in public life prompts conflicts due to their inexperience, little knowledge and skills. The volunteer movement, which allows the younger generation to realize their aspirations by assisting the weak and supporting innovative projects in various fields, is intended to resolve this contradiction. The analysis of modern research confirms that volunteerism plays a key role in mobilising the public initiative and serves as an effective means of solving many social problems (Solsrud; Bankova, 2014; Petkova, 2008; Hasan, 2016a).

It should be noted that there are certain difficulties in organizing voluntary activities. Young people, according to their age characteristics, do not possess knowledge and preparation to provide a voluntary aid, which in practice often leads to problems of a different nature. Often volunteers fall into situations where not only compassion and mercy are needed, but also the ability to work in a team with representatives of different ages, in the settings of institutions of different nature and types. There is a need for a comprehensive training of volunteers, which includes a special educational programme targeting the shaping of trainees' ideas about the voluntary movement and the various forms of organization of voluntary activities. This program should be practice-oriented and include modern technologies and methods of teaching. This is the so-called work in master classes, which allow for accumulation of experience and practical knowledge, in which volunteers study sociotherapeutic, psychological, pedagogical methods and ways of solving specific human life problems and discussions. Thus, conditions are created for joint search for answers to questions of different nature encountered in the practice of the volunteer. These are also so-called game forms, club meetings, etc. The relevance of attracting children and teenagers in the field of volunteerism is also confirmed by the data on increasing criminality among adolescents (Hasan, 2016b; Vassilev, Kavrakov, 2014).

\section{MODEL FOR INSTITUTIONAL REGULATION OF VOLUNTEERISM AS A SOCIAL COMMUNITY}

The model of relations between the state and the "third sector", which exists in each country, is the product of various local factors: religion, demography, history, ethnic structure, ideology, politics, economics, etc. The models and the framework of institutional regulation of volunteering (macro-level management of volunteers) in countries such as the United States, China and Germany (countries representing Western, Eastern and European societies) were examined. The etymology of the term "model" originates from the Latin word 
"modus," which means the way an object or process exists or is perceived. Thus presented the model is a new, artificially created object that reflects the essential characteristics of the research object, phenomenon or process and presents it; it is a system, the study of which will serve as a means of obtaining information about another system. The examination of models for regulating volunteering in the United States, Germany and China is aimed at obtaining new knowledge in the course of comparative analysis and at identifying methods and means to improve institutional regulation of volunteering.

The study of the characteristics and key positions of institutional regulation of volunteerism in foreign countries is due to the need to improve the current institutional conditions for the functioning of the social community of volunteers, without which it cannot exist and develops effectively. The basis of the comparative analysis of the patterns of state regulation of volunteers in the United States, Germany and China is based on the following criteria (Table 1):

1. Institutional regulation (legal regulation, as well as bodies responsible for implementing volunteerism policies);

2. Main areas of support and incentive of volunteering;

3. Target audiences of government assistance and incentive programmes;

4. Incentive and assistance programmes (insurance, tax breaks, bonuses, rewards, compensation of expenses);

5. Model of the relationship between the state and the community of volunteers ("partnership", "paternalism", "confrontation", model of "ignoring").

Table 1 Adjustment of volunteering at macro level in the United States, Germany and China

\begin{tabular}{|c|c|c|}
\hline USA & Germany & China \\
\hline \multicolumn{3}{|c|}{ 1. Areas of volunteerism, most up-to-date from the point of view of public administration } \\
\hline $\begin{array}{l}\text { 1. Coping with the effects of } \\
\text { natural disasters. } \\
\text { 2. Fight against poverty. } \\
\text { 3. Education. } \\
\text { 4. Environmental protection } \\
\text { (environmental volunteerism). } \\
\text { 5. Healthcare. } \\
\text { 6. Support to veterans and familie } \\
\text { of militaries }\end{array}$ & $\begin{array}{l}\text { 1. Sports volunteerism. } \\
\text { 2. Development of villages and } \\
\text { rural regions. } \\
\text { 3. Integration of migrants. }\end{array}$ & $\begin{array}{l}\text { 1. Event volunteerism (sports, } \\
\text { EXPO, Olympic Games). } \\
\text { 2. Coping with the effects of } \\
\text { natural disasters, volunteer } \\
\text { emergency action service. } \\
\text { 3. Environmental volunteerism } \\
\text { (environmental protection). } \\
\text { 4. Support of vulnerable groups } \\
\text { of the population (social } \\
\text { volunteerism). }\end{array}$ \\
\hline \multicolumn{3}{|c|}{ 2. Target audience of the assistance and incentive programme } \\
\hline $\begin{array}{l}\text { 1. Youngsters ( } 18-24 \text { years old) } \\
\text { 2. Adults (over } 50 \text { years old) }\end{array}$ & $\begin{array}{l}\text { 1. Youngsters and students. } \\
\text { 2. Adults. }\end{array}$ & 1. Youngsters. \\
\hline \multicolumn{3}{|c|}{$\begin{array}{l}\text { 3. Institutional regulation (legal regulation, as well as authorities responsible for implementing } \\
\text { volunteerism policies) }\end{array}$} \\
\hline $\begin{array}{l}\text { The main coordinating body at } \\
\text { national level: The Corporation of } \\
\text { National and Community Service } \\
\text { (CNCS). Branches of the } \\
\text { corporation are represented across } \\
\text { the country. Legal acts define the } \\
\text { concept of "volunteer" in the legal } \\
\text { field and regulate the rights of } \\
\text { volunteers. Great attention in the }\end{array}$ & $\begin{array}{l}\text { The main coordinating body at } \\
\text { national level is the Federal } \\
\text { Ministry of Family, Elderly, } \\
\text { Women and Youth. Large } \\
\text { network organizations (Federal } \\
\text { Network for Citizenship Activity, } \\
\text { National Organization of } \\
\text { Voluntary Agencies and } \\
\text { Organizations) operate }\end{array}$ & $\begin{array}{l}\text { The main coordinating body at } \\
\text { national level: the Committee on } \\
\text { Problems and Spiritual } \\
\text { Governance of the Communist } \\
\text { Party of China. Network } \\
\text { organisations operating across } \\
\text { the country: } \\
\text { 1. Communist Union of Youth }\end{array}$ \\
\hline
\end{tabular}




\begin{tabular}{|c|c|c|}
\hline $\begin{array}{l}\text { legislation is paid to the protection } \\
\text { of volunteers. At national level, the } \\
\text { requirements for support } \\
\text { programmes, selection } \\
\text { requirements, obligations, } \\
\text { responsibilities and accountability } \\
\text { are clearly defined. }\end{array}$ & $\begin{array}{l}\text { throughout the country. The } \\
\text { legislation concerns mainly the } \\
\text { insurance of the life and health of } \\
\text { volunteers and the provision of } \\
\text { preferential taxation. }\end{array}$ & $\begin{array}{l}\text { (CYL) is the broadest and most } \\
\text { powerful network organization. } \\
\text { 2. Association of Volunteers in } \\
\text { China. } \\
\text { The legal framework for } \\
\text { volunteerism has existed since } \\
2010 \text {. From } 2001 \text { to } 2009 \text {, there } \\
\text { were only legal initiatives, related } \\
\text { to certain types of volunteerism: } \\
\text { student volunteering, female } \\
\text { volunteering, rural development } \\
\text { and incentive of volunteerism. } \\
\text { Many organizations do not have } \\
\text { legal status. }\end{array}$ \\
\hline
\end{tabular}

4. Programs for incentive and assistance

\begin{tabular}{|c|c|c|}
\hline $\begin{array}{l}\text { A system of differentiated } \\
\text { programs, grants and awards } \\
\text { (AmericCorps program, } \\
\text { SeniorCorps, Social Innovation } \\
\text { Fund, Voluner Generation Fund). } \\
\text { The programs include } \\
\text { compensations, medical care, } \\
\text { accommodation, uniforms, food } \\
\text { and more. The official website of } \\
\text { the Corporation regularly publishes } \\
\text { news, reports on the contribution } \\
\text { of volunteer labor, maintains an } \\
\text { official blog, also hosts events and } \\
\text { happenings that promote } \\
\text { volunteerism. }\end{array}$ & $\begin{array}{l}\text { Over } 50 \text { initiatives, projects and } \\
\text { programmes for groups of } \\
\text { different ages. Numerous events, } \\
\text { happenings and awards. } \\
\text { Provision of insurance, } \\
\text { preferential taxation, } \\
\text { compensation of costs. }\end{array}$ & $\begin{array}{l}\text { Programs in China are divided } \\
\text { into blocks: } \\
\text { 1. Support to major national } \\
\text { events. } \\
\text { 2. Programs for support to poor } \\
\text { regions. } \\
\text { 3. Support programmes for } \\
\text { volunteer teams fro emergency } \\
\text { response. } \\
\text { 4. Corporate volunteerism, } \\
\text { support for private sector } \\
\text { volunteers. } \\
5 \text {. International programs for } \\
\text { support of volunteers. }\end{array}$ \\
\hline \multicolumn{3}{|c|}{ 5. The model of relations between the state and the community of volunteers } \\
\hline $\begin{array}{l}\text { - "Partnership." } \\
\text { - "Model of gardeners": } \\
\text { authorities at different levels adopt } \\
\text { regulations promoting the } \\
\text { emergence and development of } \\
\text { independent public organizations, } \\
\text { the development of volunteerism } \\
\text { and take concrete actions for } \\
\text { support and development. }\end{array}$ & $\begin{array}{l}\text { "Paternal" } \\
\text { The dominant role of the } \\
\text { authority manifests itself in the } \\
\text { independence of voluntary } \\
\text { organizations and their } \\
\text { dependence solely on state } \\
\text { funding. }\end{array}$ & $\begin{array}{l}\text { "Paternal" } \\
\text { Authority dominance is due to } \\
\text { the country's dominant political } \\
\text { regime. The state allows some } \\
\text { autonomy to organizations and } \\
\text { volunteers in exchange for } \\
\text { political loyalty, also provides } \\
\text { some support for the activities of } \\
\text { loyal organizations (funding, } \\
\text { benefits and preferences) and } \\
\text { voluntary movements. }\end{array}$ \\
\hline
\end{tabular}

The different grounds and forms of presentation of the data on the development of volunteerism in these countries, as well as cultural, historical features and differences in the stages of development of volunteerism create difficulties in the analysis.

American model of institutional regulation of social community of volunteers. The US can rightly be considered the state with a high level of popularity of volunteering among the population and extensive experience in managing volunteer activities. In the US, it plays a significant role in the life of various social groups, in organizational terms it is widespread and involved in the activities of numerous organizations of the third sector and is practically found in almost all spheres of public life: social, cultural, political, etc. A 
specific feature of volunteering, which is characteristic only for the US, is assisting veterans and families of military personnel, which may be related to the country's foreign policy. In addition, serious support from the government receives such a direction of voluntary work as eliminating the effects of natural disasters, which relates to geographical location and climatic conditions.

The institutional conditions for the functioning of the social community of volunteers are expressed in the legal regulation of volunteerism in the United States, which consists of numerous legal regulations governing the behavior of volunteers, as well as ensuring their rights and responsibilities and targeting mainly to the protection of volunteers. The United States is the only state where volunteering is controlled by a separate specialized independent federal agency, rather than by one of the executive bodies of the federal government, that combines volunteering management with its core activity (as occurs in Germany and China) (Bankova, Dimitrov, 2012; Hasan, 2018a; Petrova, Petrov, 2020b).

Main advantages of the model of legal regulation of volunteering in the United States are the availability of:

1. A regulatory and legal act that distinguishes the powers of state institutions and voluntary organizations. It also determines responsibility and protects the interests of volunteers;

2. A specialized federal body that provides coordination, incentive and promotion of volunteerism in the country, taking into account the interests of all parties (state, volunteers, non-profit organizations, etc.).

Regarding the encouragement of volunteerism by the US state, it can be said that the support of volunteerism was carried out in stepwise, through the implementation of various national programmes. At every stage of the development of voluntary activities, the state actively intervenes and stimulates this development not only at national, but also at regional and local level. US law provides for compensations for volunteers with public funds. Many states allow volunteers working in hazardous conditions (such as firefighters or assistants of law enforcement authorities) to receive compensation (Study on Volunteering in the European Union Country Report Germany, 2009). In the United States there is a system of diverse support and incentive programs (reimbursement of costs, tax breaks, scholarships, bonuses, awards) that are differentiated in accordance with the socio-demographic characteristics of volunteers. This is an essential feature of the model for regulating volunteering in the US.

The most characteristic parameters of the German model of institutional regulation of the social community of volunteers are expressed in the institutional conditions for the functioning of the social community of volunteers in Germany. They are represented in a developed network of federal ministries, federal agencies and network organizations that are responsible for numerous projects, initiatives and events. Legal acts governing the activities of the social community of volunteers in Germany relate to insurance and taxation. Specific legal status for volunteers as a whole in Germany does not exist; volunteers must act under general legal conditions that partially regulate public work, aiming to protect volunteers. Although relations between volunteers and host organisations are not considered an employment relationship, they are seen as the equivalent of employment in accordance with public law. As a result, relevant employee protection rules also apply to volunteers. Some volunteers receive insurance for health, for accidents, for unemployment, etc. Institutional regulation of voluntary activity at the federal level is carried out by the Federal Ministry of Family, Elderly, Women and Youth. Since 1999, a special department in the Ministry has been responsible for volunteerism at national level (State of volunteerism in China. Engaging People through Ideas, Innovation and Inspiration, 2011).

The disadvantages of the voluntary regulation model in Germany are:

1. Lack of clear coordination of efforts of all federal ministries, disaccord in the management of various aspects of volunteerism among executive bodies of state power;

2. Difficulties with sustainable funding of non-profit organizations (reducing the maximum duration of family allowances, introducing tuition fees in some federal states, which has a negative effect on volunteering).

Stakeholders believe that sustainable funding is a key factor in developing strategic long-term projects and retaining staff. The problem is that a high proportion of volunteer centers depends on state subsidies, which are limited to a certain period (2-3 years). Due to the fact that funding is not sustainable, it is difficult to invest in projects and infrastructure. It can be said that non-profit organizations are dependent on state support, which contradicts the understanding of the "third sector" as a "counterweight" to the state, as an independent participant in the structure of public relations and speaks of "Paternal" model of relations between the state and"the third sector."

The advantages of institutional regulation of volunteering in Germany are: 


\section{Special attention is paid to the problem of life standard and health insurance of volunteers}

2. The presence of a federal network of civil activity, uniting various participants and implementing their interaction.

Preferential taxation can stimulate the population to participate in volunteering activities and to make donations to "third sector" organisations, which will allow NGOs to gain greater independence and development potential. Among the specific areas of volunteer work supported by the German state, it is worth noting the participation of volunteers in promoting the integration of migrants. This problem is one of the most acute for the state and requires additional resources to solve it, the source of which may be the volunteers. Volunteerism acts as a tool to ensure social cohesion in the context of demographic change by mobilising young people to solve social problems and exploiting the experience and knowledge of the older generation (Petrova, Petkova-Georgieva, 2020a; Vassilev, Tanev, Kavrakov, Abrashev, 2015).

In Germany, as well as in the US, work is actively being carried out to stimulate volunteerism (support programmes, awards, events, tax incentives, information work, etc.). The Federal Ministry of Family, Elderly, Women and Youth has over 50 different initiatives, projects and programs related to volunteerism ("Year of Volunteer Social Services", Project "Volunteering for All", Project "Initiative for Me, for Us, for All", "Week of civic activity ", "Volunteer Day", "Social Day", etc.). The federal government provides financial support for volunteerism, for example, by providing specific measures for tax aid or government funding. Support plans vary in different programs. Both federal and regional authorities have implemented various measures to reimburse expenses of government volunteers that relate to their participation in volunteering. Such expenses most often include transportation, fuel, etc. The rules on reimbursement and taxation are governed by the specific parameters of each programme.

A Chinese model of institutional regulation of the social community of volunteers can be seen after 2001, when state and local governments began implementation of a policy to promote volunteerism through legal regulation, administration and support. The key government bodies for volunteerism in China are the Committee on Spiritual Governance, the Ministry of Civil Affairs and the Chinese Communist Youth Union. In addition, volunteers are regulated through government-run NGOs (GONGO). The National Volunteer System in China is a complex system of integration and coordination between party committees, state youth league, youth volunteer association, public and social organizations, non-profit organizations, charity organizations and business community at national and local level. The Communist Youth Union Voluntary Service System $(C Y L)$ remains the widest and most powerful mobilisation network that has built an effective mechanism in terms of information, recruitment, mobilisation, preparation, management, evaluation of the work of volunteers and fund raising. The activities of this network have become an important factor in the institutionalisation of volunteerism in China (The Corporation for National and Community Service). Despite the rather extensive network of bodies that promote the development of volunteerism, there are quite significant gaps in the legal regulation of volunteerism and in the coordination of efforts of various state bodies.

One of the most striking features of volunteering in China is that it develops in close cooperation between government and volunteer organizations. The state changes the nature of the relationship: from the initial predominance of political and economic leadership to the provision of public services, from the initial state centralization to cooperation between the state, society and business. Gradually, the "Paternal" model of relations between the state and the "third sector" was transformed into a partner model. Volunteerism as a social phenomenon plays an important role in the political, economic, cultural and social domains of society. With regard to China, it should be noted the role of volunteerism in the social and economic domains ("filling the failures of the state" without material investment), which conveys the ancient national culture and tradition of this country. In the political domain, it is difficult to talk about independence of the "third sector" and the volunteerism as one of its key elements in relation to the political system and structure of that country. It should rather be said about volunteerism that it is one of the state's "tools" for solving social issues and problems.

The main disadvantage of the model of state regulation of volunteerism in China are the gaps in the legal field (the lack of legal acts protecting the interests of volunteers, providing insurance for their life and health), which is also characteristic of the reality in the former socialist countries. The main advantage of the Chinese model is the availability of a federal network of volunteers, which has significant rights and means for the development of volunteering. Such network centers were created within the preparations for the Universiade and the Olympic Games, which served as an impetus for the formation of regional volunteer centers on the basis of higher education institutions. 
Volunteer programmes and events in China can be classified as follows:

- Participation in large-scale events (Olympic Games, EXPO).

- Poverty reduction.

- Support for vulnerable groups, including support for young people, the disabled, the elderly and the poor, as well as protection of the environment.

- Volunteer Emergency Response Service.

- Private sector and corporate volunteerism.

- International volunteerism.

The modern volunteering system in China is formed under the important influence of European practice and American experience. As a result of internal reforms and openness to the outside world, focused on international cooperation, China has embraced the experience of Western nations. International Partnership and Cooperation (with Japan, USA, Australia, Korea) is considered one of the main methods for solving the problems of governance, training, regulation and capacity building of Chinese volunteer organizations. For the implementation of international volunteer programs, key organizations are the Chinese International Center for Economic and Technical Exchange and the Chinese Association of NGOs at the Ministry of Commerce. The problems in China are:

1. Lack of public perception of volunteers;

2. The need for a more reliable and diverse volunteering structure to respond to the impact of the rapid development of Chinese society;

3. Absence of clear regulation of different types of volunteerism;

4. Problems with management, absence of systematic methods of managing volunteers;

5. Shortcomings in the system of preparation and education of volunteers;

6. Need to reduce to a large extent the role of the state in order to form sustainable volunteerism that does not depend on major state events;

7. Lack of resources (financial, intellectual), institutional support;

need for a legal framework and development of a system for registering volunteers (The Corporation for National and Community Service).

\section{CONCLUSION}

Based on a comparative analysis of the American, German and Chinese model of institutional regulation of volunteerism, measures that need to be done by our country may be outlined:

1. To develop regulatory acts to ensure protection of the responsibility of volunteers, provide insurance for the life and health of volunteers (the law defining the concepts of volunteerism and regulating the obligations of volunteers and the state remains insufficient);

2. Coordination of voluntary organizations and volunteers at the state level (executive power, state agency or state network, etc.);

3. Creation of an Internet portal as the main source of information on the needs of volunteerism (database);

4. A clear definition of the sequence of actions for a citizen who wishes to become a volunteer and be useful to his society (publication of information on the Internet portal, publication of the appropriate application form);

5. a clear definition of the sequence of actions for non-profit organizations wishing to submit an application for the need for volunteers, their characteristics and conditions of participation (also publication on the Internet portal);

6. Organisation, financial support and development of volunteerism:

- Educational, training programs

- Scholarship (incentive) programs (reimbursement of costs for training voluntary activities, payment of monthly scholarships); 
- Programmes to promote volunteerism (among students and adolescents);

- Programmes to support voluntary activities for adults.

7. Implementation of priority areas that are most acutely in need of volunteering, regulating the attraction of volunteers in problem areas;

measuring the results of voluntary activities, contribution of volunteers, maintenance of statistics and presentation of annual reports.

\section{REFERENCE LIST}

Solsrud, A. Laws on volunteering [Electron Resource]. - Access mode: http://www.ehow.com/facts_7586067_laws-volunteering.html.

Study on Volunteering in the European Union Country Report Germany. - 2009.

State of volunteerism in China. Engaging People through Ideas, Innovation and Inspiration. - 2011.

The Corporation for National and Community Service [Electron Resource]. - Access mode: http://www.nationalservice.gov/about/volunteering/government.asp

Bankova, I. T., Dimitrov, S. (2012). Characteristics and some problems of Afghanistan's public administration. Tribal agreements - an alternative supporting establishment of modern public administration, The 20th NISPAcee Annual Conference 'Public Administration East and West: Twenty Years of Development', May 23 - 26, 2012, Ohrid, Republic of Macedonia (FYR Macedonia)", ISBN 978-80-89013-63-0

Bankova, I. (2014). Administrative Conflicts in Bulgarian Regional Development Policy - Current, Situation, Trends, Possible Solutions. Regionalisation and Regional Policy in Central and Eastern Europe. Book Selectet Riversed Papers from the 21st NISPAcee Annual Conference 'Public Administration Of The Future', 16-18 May 2013. Belgrade, Serbia. 2014. ISBN 978-80-89013-73-9. p.305-317.

Hasan Azis, (2016a). Qualitative Changes in Municipalities in the Absorption of Structural Funds and the Impact of Decentralization on Their Achievement (The Example of Kardzhali), Assen Zlatarov University Annual, Vol. XLV, Book 2, Burgas, 2016, pp. 248-250, ISSN 1312-1359

Hasan Azis, (2018a). Quality and perspectives for administrative management development according to the decentralization process in Greece, Public archive, Svistov, vol.3, 2018 0323-9004 (print), 2367-9301 (online)

Hasan Azis, (2016b), Naglasi i udovletvorenost spryamo detsentralizatsiyata v Bulgaria, Psihologichni izsledvania, Volume 19, Number 2, 2016, str. 99-111, ISSN 1311-4700 (print), ISSN 2367-4563 (online)

Petrova Teodora, Petkova-Georgieva Stoyanka, (2020a). Motivatsionen model za razvivane na savremenen meditsinski turizam, Elektronno spisanie "SCIENTIFIC ATLAS", 2020, № 1, ISSN 2738-7518

Petkova, S. (2008). Balanced scorecard as instrument of strategic controlling. // Forum Gesundheit und Soziales, Beitrage aus Lehre, Forschung und Praxis der Studiengange der Evangelischen Fachhochschule, Berlin, 2008, Heft 6, pp. 60 - 68, ISSN 1863-1851

Petrova Teodora, Petrov Zhivo, (2020b). Alternative Approaches for Long-Term Defence Planning, Proceedings of SOCIOINT 2020-7th International Conference on Advances in Education and Social Sciences, 20-22 January, 2020-Dubai, U.A.E., pp. 818-825, ISBN 978-605-82433-8-5

Vassilev, V., Tanev D., Kavrakov T., Abrashev H., (2015). Our experience in surgical treatment of the complicated forms of colorectal cancer, Trakia journal of scientific, ISSN 1313-7050, 2015

Vassilev V., Kavrakov T., (2014). Diabetic foot - phenomenon or complications of diabetes, International scientific on-line journal "Science \& Technologies", Publisher "Union of Scientists - Stara Zagora", IV; $1 ; 2014$, ISSN 1314-4111 